\title{
A Decade of Development of Ethylidenethiosemicarbazides as Building Blocks for Synthesis of Azoles and Azines (A Review)
}

\author{
SAYED M. RIYADH ${ }^{1,2, *}$, SHOJAA ABED EL-MOTAIRI ${ }^{1}$ and ANWAR A. DEAWALY ${ }^{1}$ \\ 'Department of Chemistry, Faculty of Science, Taibah University, Al-madinah Al-munawrah, \\ 30002, Saudi Arabia. \\ ${ }^{2}$ Department of Chemistry, Faculty of Science, Cairo University, Giza, 12613, Egypt. \\ *Corresponding author E-mail: riyadh1993@ hotmail.com
}

http://dx.doi.org/10.13005/ojc/340201

(Received: February 26, 2018; Accepted: March 30, 2018)

\section{ABSTRACT}

This review represents the synthesis of ethylidenethiosemicarbazides, with aryl or heterocyclic moieties, and its utility as building blocks for construction of different heterocyclic compounds such as; thiazoles, thiazolidinones, [1,3,4]thiadiazoles, [1,3,4]triazoles, [1,3]thiazines, pyrimidines, thiazolo[5,4-b]quinoxalines, bis-thiazoles, and bis-pyrazoles. Also, the pharmaceutical applications of ethylidenethiosemicarbazides have been demonstrated.

Keywords: Thiosemicarbazones, Azoles, Azines, Cyclocondensation, Biological Activity.

\section{INTRODUCTION}

Ethylidenethiosemicarbazides [(ethylidene) hydrazine carbothioamides) are a class of organic compounds with general structure
$\left[\operatorname{Ar}\left(\mathrm{CH}_{3}\right) \mathrm{C}=\mathrm{N}-\mathrm{NH}-\mathrm{CS}-\mathrm{NH}_{2}\right]$. Variation of substituents on thioamide nitrogen $(A)$, sulfur atom $(B)$, and hydrazone nitrogen (C) led to developing an array of ethylidenethiosemicarbazides with structural diversity and broad spectrum of biological activities (Figure 1).<smiles>[R]N([R])C(=S)NN=C(C)[GeH3]</smiles>

(A)<smiles>[R]SC(N)=NN=C(C)CCCCCC</smiles>

(B)<smiles>[R1]N(/N=C(/C)[GeH2])C(N)=S</smiles>

(C)

Fig. 1. Representative derivatives of ethylidenethiosemicarbazides

This is an 2 Open Access article licensed under a Creative Commons Attribution-NonCommercial-ShareAlike 4.0 International License (https://creativecommons.org/licenses/by-nc-sa/4.0/ ), which permits unrestricted NonCommercial use, distribution and reproduction in any medium, provided the original work is properly cited. 
Recently, ethylidenethiosemicarbazides have been used as effective pharmacophoric agents in medicinal chemistry such as; antitumor ${ }^{1}$, anti-tubercular ${ }^{2}$, anti-amoebic ${ }^{3}$, anti-fungal ${ }^{4}$, antiviral $^{5}$, antimicrobial ${ }^{6}$, antioxidant ${ }^{7}$, anticonvulsant ${ }^{8}$, and anti-trypanosomal ${ }^{9,10}$. Also, these compounds were prescribed for treatment of hypertension as calcium channel blockers ${ }^{11}$. The biological activity of ethylidenethiosemicarbazides is related to their chelating ability with metal ion through either thione or thiolate sulfur and one of the hydrazone-nitrogen atoms ${ }^{12}$. Furthermore, ethylidenethiosemicarbazides have been used as a reactive building blocks for synthesis of different azoles such as, bis-thiazoles ${ }^{13}$,
$[1,3,4]$ thiadiazoles $^{14},[1,3,4]$ oxadiazoles $^{15}$, thiazolidin-4ones $^{16}$, imidazolinones ${ }^{17}$, and thiazoles ${ }^{18,19}$. In this survey, we represent three approaches about ethylidenethiosemicarbazides, with different aryl or heterocyclic moieties, including synthesis, reactivity, and their biological activities.

\section{Synthesis of ethylidenethiosemicarbazides}

Ethylidenethiosemicarbazides with aryl group (compound 3 ) or heterocyclic moiety (compound 5) were prepared through condensation reactions of thiosemicarbazide (1) with acetylarene 2 or heterocyclic ethanone4, respectively [Scheme 1 and Tables 1,2]<smiles>CCC(C)=O</smiles><smiles>CC(=O)CCCCC(C)=O</smiles>

Scheme 1. Synthesis of ethylidenethiosemicarbazides

Table 1: 1-(1-arylethylidene)thiosemicarbazide derivatives

\begin{tabular}{c} 
Ref. \\
\hline
\end{tabular}

Table 1(continued) 


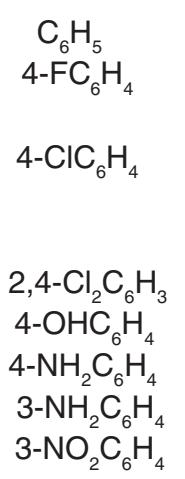

[20-22] 2-(OH)-5- $\left(\mathrm{CH}_{3} \mathrm{O}\right) \mathrm{C}_{6} \mathrm{H}_{3}$ 2-(OH)-5- $\mathrm{BrC}_{6} \mathrm{H}_{3}$

[23]

[24]<smiles>Cc1ccc(NC(=O)CN2C(=O)c3ccccc3S2(=O)=O)cc1</smiles><smiles>C=Cc1ccc(COc2ccc(C)cc2)cc1</smiles><smiles>Cc1ccc(NC(=O)c2ccccc2C(=O)O)cc1</smiles><smiles>Cc1ccc(NC(=O)CC#N)cc1</smiles>

[37]<smiles>Cc1ccc(NC(=O)/C(C#N)=C/[Na])cc1</smiles>

[37]<smiles>Cc1ccc(N2CN(C)c3ccccc3C2=O)cc1</smiles><smiles>Cc1ccc(NC(=O)c2cc3ccccc3oc2=N)cc1</smiles><smiles>Cc1ccc2ccccc2c1</smiles>

$[21,42]$<smiles>Cc1ccc(-n2c(C)ccc(C#N)c2=O)cc1</smiles><smiles>Cc1ccc2c(c1)CCCC2</smiles><smiles>Cc1ccc(-n2c(N)c(C#N)c(C#N)c(C#N)c2=O)cc1</smiles><smiles>Cc1cccc2cc3ccccc3cc12</smiles><smiles>Cc1ccc2ccc3cccc4ccc1c2c34</smiles>

Table 1(continued) 


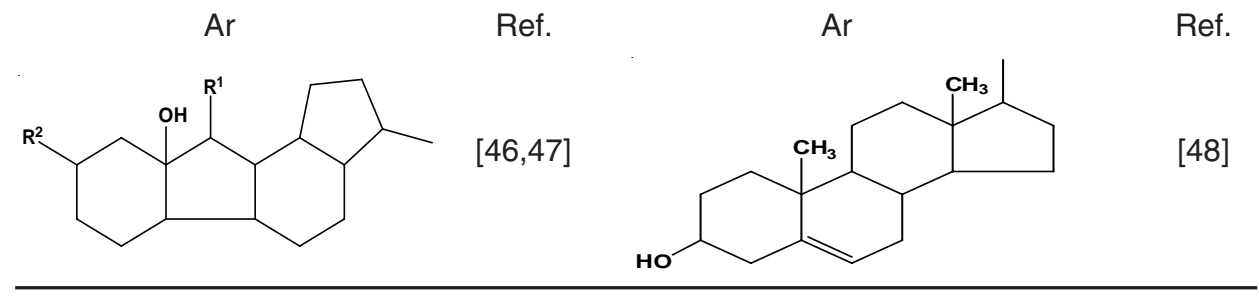

Table 2: Ethylidenethiosemicarbazides with heterocyclic moiety

[21,49]

Table 2(continued)

[20-22] Ref.

Table 2(continued) 
<smiles>Cc1cc2ccccc2s1</smiles>
Het<smiles>COC1=CC2C(C)CC(OC)C(OC)CC2C1C</smiles><smiles>Cc1sc2nc3ccccc3nc2c1-n1cccc1</smiles><smiles>Cc1sc2c(-c3ccccc3)c3c(nc2c1-n1cccc1)/C(=C/c1ccccc1)CCC3</smiles>

[51]<smiles>Cc1cc(-c2cnccn2)cc2ccccc12</smiles>

[69]<smiles>Cc1c(O)c2ccccc2[nH]c1=O</smiles>

Het

Ref.
[73]

[74]<smiles>Cc1cc2c(ccc3ccccc32)o1</smiles>

Ref.<smiles>Cc1sc2nc3sc4c(c3c(=O)n2c1C)CCC4</smiles>

Reactions of ethylidenethiosemicarbazides Reaction with $\alpha$-ketohydrazonoyl halides

5-Arylazothiazoles 7 were synthesizedvia reactions of ethylidenehydrazine-1-carbothioamides3 or 5 with $\alpha$-ketohydrazonoyl halides $6[N$-aryl 2-oxopropanehydrazonoyl chlorides or $\mathrm{N}$-aryl 2-substituted-acetohydrazonoyl bromides] under thermal conditions $6,7,18,19,42,43,53,57,70,80-86$ (Scheme 2).

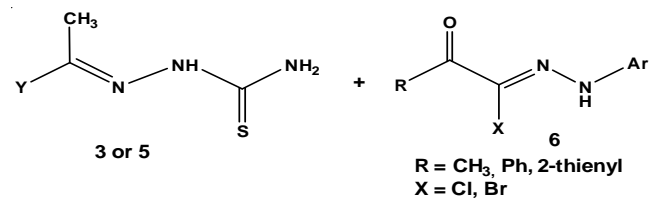<smiles>[Y]C(C)=NNc1nc([R])c(N=N[V])s1</smiles><smiles>Cc1ccc(N=Nc2ccc(O)cc2O)cc1</smiles><smiles>CC1=NN([Al])C(=O)C1C</smiles><smiles>Cc1cnn(-c2ccccc2)c1C</smiles><smiles>Cc1c(-c2cccs2)nn(Cl)c1C</smiles><smiles>Cc1nc(S)n(C)c1C</smiles><smiles>Cc1nc(-c2ccccc2)[nH]c1C</smiles><smiles>Cc1nnn(-c2ccccc2)c1C</smiles><smiles>Cc1n[nH]c(=NC(=O)O)s1</smiles>
$\&$<smiles>Cc1ccccn1</smiles><smiles>Cc1cc2ccccc2[nH]1</smiles><smiles>Cc1cc2ccccc2o1</smiles><smiles>Cc1cc2cc(Br)ccc2oc1=O</smiles><smiles>Cc1cc2ccccc2oc1=O</smiles>

Scheme 2. Reaction of ethylidenehydrazine-1-carbothioamides with $\alpha$-ketohydrazonoyl halides 
By analogous method, ethylidenehydrazine1-carbothioamides3 or 5reacted with ethyl $\mathrm{N}$-aryl2-chloro-2-hydrazono acetate 8 under reflux conditions in dioxane, containing catalytic amount of triethyl amine and afforded arylhydrazothiazolone ${ }^{81,85}$ derivatives 9 (Scheme 3 ).<smiles>[Y]C(C)=NNC(N)=S</smiles><smiles>CCOC(=O)/C(Cl)=N/N[Tl]</smiles>

8<smiles>O=C(N=c1sc([In])nn1-c1ccccc1)c1ccccc1</smiles><smiles>Cc1c(-c2cccs2)nn([AlH2])c1C</smiles><smiles>[Y]C(C)=NNC1=NC(=O)/C(=N\N[Ga])S1</smiles>

Scheme 3. Reaction of ethylidenehydrazine-1-carbothioamides with ethyl $\mathrm{N}$-aryl-2-chloro-2hydrazono acetate

The reactivity of thiosemicarbazones 3 or 5 towards $\mathrm{N}$-aryl carbohydrazonoyl chlorides 10 , without keto group, has been reported ${ }^{18,19,84}$ under thermal ${ }^{19,84}$ or microwave irradiation and using grafted chitosan ${ }^{18}$ or triethylamine ${ }^{19,84}$ as basic catalyst. These reactions have been established to give $[1,3,4]$ thiadiazoles 11 (Scheme 4).<smiles>[Y]C(C)=NNC(N)=S</smiles>

Scheme 4. Reaction of thiosemicarbazones with $\mathrm{N}$-aryl carbohydrazonoyl chlorides

\section{Reaction with bis-hydrazonoyl chlorides}

Two equivalents of thiosemicarbazones 3 or 5 were reacted with bis-[ $\alpha$-ketohydrazonoyl chlorides]12 in dioxane, in the presence of catalytic amount of triethylamine, to furnish the corresponding bis-(hydrazonothiazoles) $)^{87} 13$ (Scheme 5). 
2<smiles>[Y]C(C)=NNC(N)=S</smiles><smiles>[Y]C(C)=NNc1nc(C)c(/N=N/c2cccc(/N=N/c3sc(NN=C([Y])C)nc3C)c2)s1</smiles><smiles>[Y]=[V]=CC=Cc1ccc(C)cc1</smiles><smiles>Cc1cnn(-c2ccccc2)c1C</smiles><smiles>Cc1cc2ccccc2oc1=O</smiles>

\&<smiles>Cc1cc2c(ccc3ccccc32)oc1=O</smiles>

Scheme 5. Reaction of thiosemicarbazones with bis-[a-ketohydrazonoyl chlorides]

By the same manner, bis-hydrazonothiazoles $\quad$ with sulfonylbis-[ $\alpha$-ketohydrazonoyl chlorides]14 15 , containing sulfonyl group, were synthesized in a molar ratio (2:1), respectively ${ }^{87}$ (Scheme 6$)$. via reaction of thiosemicarbazones 3 or 5

2<smiles>[Y]C(C)=NNC(N)=S</smiles>
3 or 5<smiles>CC(=O)/C(Cl)=N/Nc1ccc(S(=O)(=O)c2ccc(N/N=C(\Cl)C(C)=O)cc2)cc1</smiles><smiles>[Y]C(C)=NNc1nc(C)c(N=Nc2ccc(S(=O)(=O)c3ccc(N=Nc4sc(NN=C([Y])C)nc4C)cc3)cc2)s1</smiles>

15<smiles></smiles><smiles>Cc1cnn(-c2ccccc2)c1C</smiles><smiles>Cc1cc2ccccc2oc1=O</smiles>
\&<smiles>Cc1cc2c(ccc3ccccc32)oc1=O</smiles>

Scheme 6. Reaction of thiosemicarbazones with sulfonylbis-[a-ketohydrazonoyl chlorides] 
Reaction with $\alpha$-halocarbonyl compounds

Treatment of 2-[(1-arylethylidene) hydrazine]-1-carbothioamides3 with 1-aryl-2- bromoethanone 16 under thermal conditions gave the respective 2-[2-(1-arylethylidene)hydrazono]-4arylthiazoles ${ }^{6,10,19,21,29,42,43,49,83,88-90} 17$ (Scheme 7).<smiles>CC(C)=NNC(N)=S</smiles>

3

16

17

Scheme 7.Reaction of arylethylidenehydrazine-1-carbothioamides with 1-aryl-2-bromoethanone

Also, refluxing of thiosemicarbazones 5, (unsubstituted)-2-bromoethanone 18 afforded with heterocyclic moiety, with 1-aryl-2-substituted 2-hydrazono-4-arylthiazoles ${ }^{49,52,55,74,76,80,84,88-9319}$ (Scheme 8).<smiles>[R]c1sc(NN=C(C)CC)nc1Br</smiles>

$18(\mathrm{R}=\mathrm{H}$, alkyl)<smiles>CCc1ccc(C)o1</smiles>

\&<smiles>Cc1cccs1</smiles><smiles>CC1C(=O)N(c2ccccc2)N=C1c1ccccc1</smiles><smiles>Cc1cnn(-c2ccccc2)c1C</smiles><smiles>Cc1nc(-c2ccccc2)[nH]c1C</smiles>
$\&$<smiles>Cc1ccncc1</smiles><smiles>Cc1c[nH]c2ccccc12</smiles>

\&<smiles>Cc1cc2ccccc2o1</smiles>

\&<smiles>Cc1cc2ccccc2oc1=O</smiles><smiles>Cc1cc2c(ccc3ccccc32)oc1=O</smiles>
$\&$<smiles>Cc1sc2nc3ccccc3nc2c1-n1cccc1</smiles>

$\&$<smiles>Cc1cc2c(ccc3ccccc32)o1</smiles>

Scheme 8.Reaction of thiosemicarbazones with 1-aryl-2-substituted (unsubstituted)-2-bromoethanone

Conversion of ethylidenehydrazine-1carbothioamides3 or 5 into 2-hydrazonothiazoles with coumarin moiety21 was achieved through their reactions with 3-(2-bromoacetyl) -2H-chromen-2-one(20) inethanol 7,21,23,71,84,86,94,95 (Scheme 9). 
<smiles>[Y]C(C)=NNC(N)=S</smiles>

Scheme 9. Synthesis of 4-(coumarin-3-yl)-2-hydrazonothiazoles

2-Arylhydrazono-5-(2-fluorophenyl) with a-bromoketone 22 in ethanolic solution thiazoles23 were synthesized from the reaction containing triethylamine as a basic catalyst ${ }^{30}$ of 1-(1-arylethylidene)thiosemicarbazides 3 (Scheme 10)<smiles>CC(C)=NNc1nc(C2CC2)c(-c2ccccc2F)s1</smiles>

Scheme 10. Reaction of arylethylidenethiosemicarbazides with $\alpha$-bromoketone

Thiosemicarbazones 3 or 5 were reacted thermal condition to give 1,4-phenylene-biswith1,4-bis-(2-bromoacetyl)benzene (24) under thiazolyl derivatives ${ }^{13} 25$ (Scheme 11).

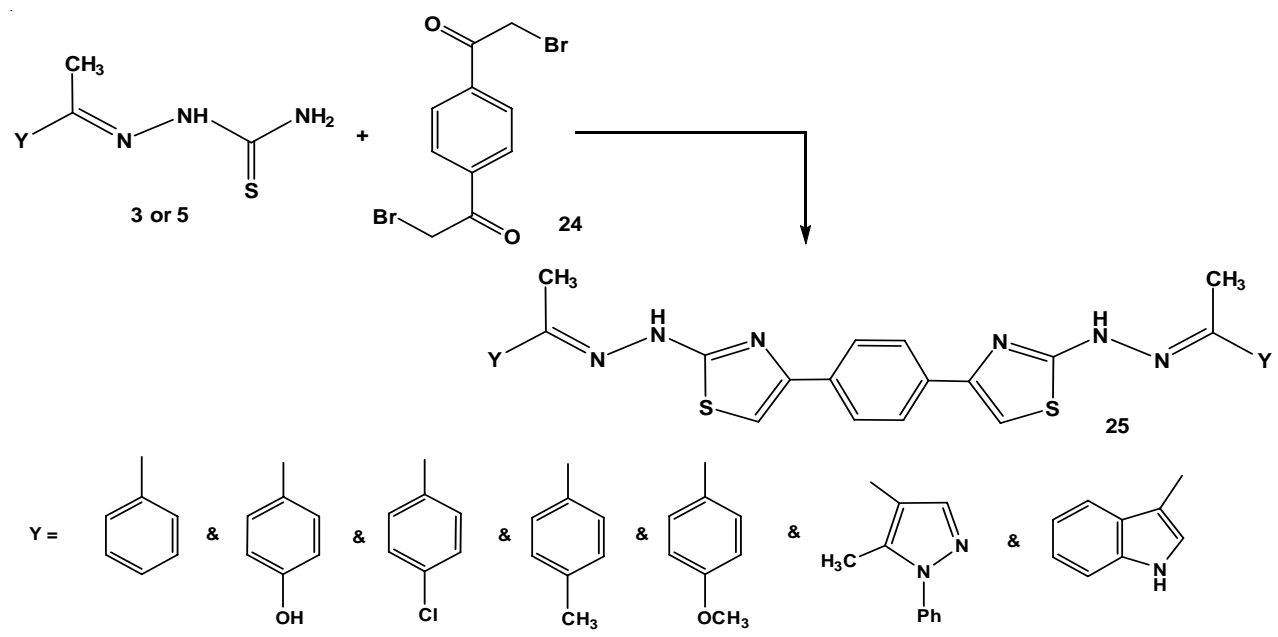

Scheme 11. Reaction of thiosemicarbazones with 1,4-bis-(2-bromoacetyl)benzene 
The reactivity of thiosemicarbazones 3 or 5 chloroacetone 26furnished the corresponding towards other a-haloketones was investigated. 4-methyl-2-hydrazonothiazoles $27^{6,10,19,42,53,78,80,83}$ Thus, treatment of 3 or 5 with (Scheme 12).<smiles>[Y]C(C)=NNC(N)=S</smiles><smiles>CC(=O)CCl</smiles><smiles>[Y]C(C)=NNc1nc(C)cs1</smiles>
3 or 5 26 27<smiles>Cc1ccc2ccccc2c1</smiles><smiles>Cc1ccc(Cl)c(Cl)c1</smiles><smiles>CC1=NN(C)C(=O)C1C</smiles>
$\&$<smiles>Cc1cnn(-c2ccccc2)c1C</smiles>

\&<smiles>Cc1cc2ccccc2o1</smiles><smiles>Cc1cc2ccccc2oc1=O</smiles><smiles>Cc1cc2c(ccc3ccccc32)oc1=O</smiles>

Scheme 12. Reaction of thiosemicarbazones with chloroacetone

Reaction with chloroethanoic acidor ethyl in ethanolic solution, containing anhydrous $\alpha$-haloalkanoate Cyclocondensation of ethylidenehydrazine-1- derivatives ${ }^{7,8,26,45,57,6029}$ (Scheme 13). carbothiamides 3 or 5 with chloroethanoic acid (28)<smiles>[Y]C(C)=NNC(N)=S</smiles>
3 or 5<smiles>[Y]=Cc1ccc(C)cc1</smiles>

\&<smiles>Cc1ccc(O)cc1</smiles>

\&<smiles>Cc1ccc2ccc3cccc4ccc1c2c34</smiles>

28<smiles>C[IH]C(=O)CCl</smiles><smiles>[Y]C(C)=N/N=C1\NC(=O)CS1</smiles>

29<smiles>Cc1cc2c(ccc3ccccc32)o1</smiles> 
Refluxing of chloroethanoic acid (28) with ethylidenehydrazine-1-carbothiamides30aor30b, in ethanolic solution containing sodium acetate, led to formation of tricyclic compounds $[2,4,6,7$ tetraazabicyclo[7.3.1]trideca-1(13),3,5,7,9,11hexaen-5-yl]thioethanoic acid (33) or $[2,4,6,7$ - tetraazabicyclo[7.2.2]trideca-1(11),3,5,7,9,12hexaen-5-yl]thioethanoic acid (34), respectively ${ }^{96}$ (Scheme 14). The reactions proceeded by nucleophilic substitution and intramolecular condensation of amino group of thiourea residue and carbonyl of amide linkage.

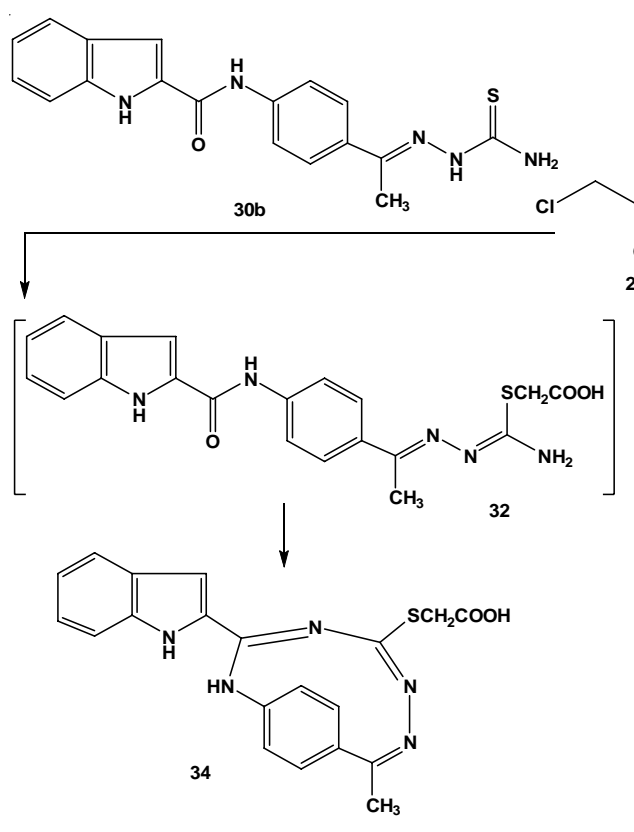

Scheme 14. Synthesis of tricyclic compounds from ethylidenehydrazine-1-carbothiamides

Cyclocondensation of bis-oxyphenylthiosemicarbazones 35 with two equivalent of chloroethanoic acid (28) gave the respective bis-

[2-(4-oxybenzylidene)hydrazono)-thiazol-4(5H)one ${ }^{26} 36$ (Scheme 15).

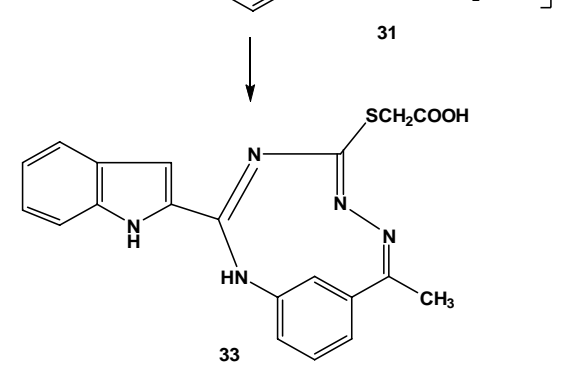<smiles>C/C(=N\NC(N)=S)c1ccc(Oc2ccc(/C(C)=N/NC(N)=S)cc2)cc1</smiles>

35<smiles>C/C(=N\N=C1/NC(=O)CS1)c1ccc(OC(C)C)cc1</smiles>

Scheme 15. Synthesis of bis-thiazol-4(5H)-one derivatives 
Treatment of ethylidenehydrazine-1- chloroethanoategave 2-hydrazonothiazolidin-4carbothioamide 5 with chloroethanoic acid or ethyl one ${ }^{72}$ (37) (Scheme 16).

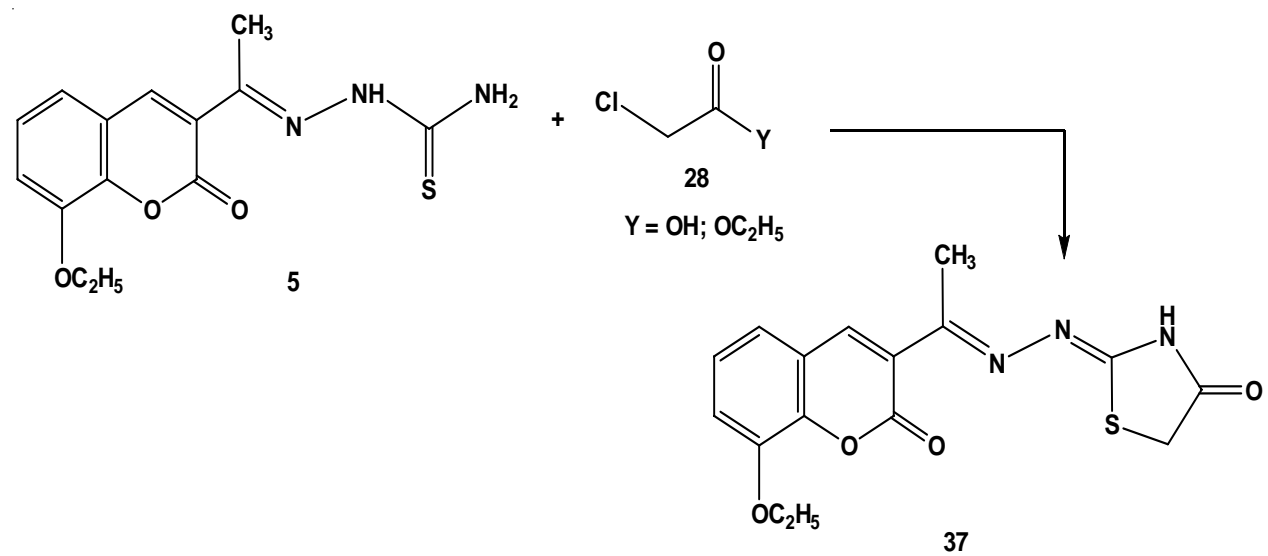

Scheme 16. Reaction of ethylidenehydrazine-1-carbothioamide with chloroethanoic acid or ethyl chloroethanoate

Conduction of 1-(1-arylethylidene) gave the respective 2-[2-(1-arylethylidene) thiosemicarbazides 3 with ethyl 2-chloro-2- hydrazono]-5-phenyl-thiazol-4(5H)-ones ${ }^{16} 39$ phenylacetate (38) under reflux conditions (Scheme 17).

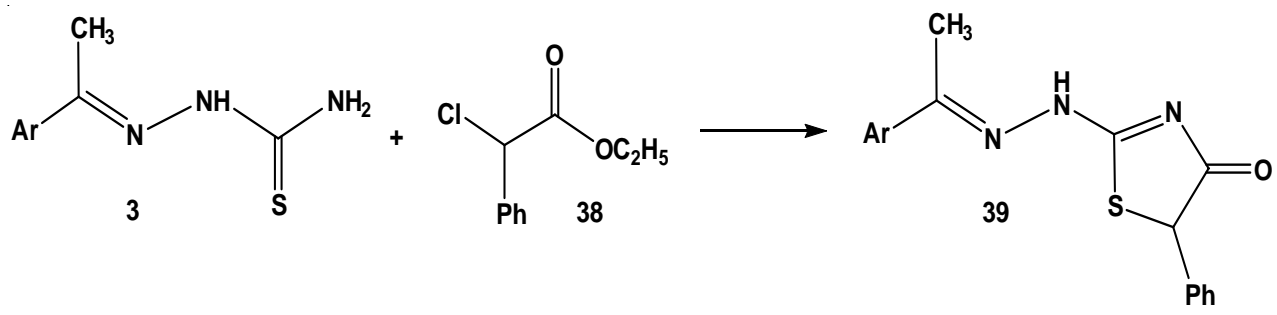

Scheme 17.Synthesis of 5-phenyl-thiazol-4(5H)-ones

Similarly, reaction of ethylidenehydrazine1 -carbothioamides 3 or 5 with ethyl bromoethanoate(40) under reflux condition in an anhydrous

potassium carbonate ethanolic solution afforded 4-thiazolidenones ${ }^{42,43,76,78,90,97} 41$ (Scheme 18).

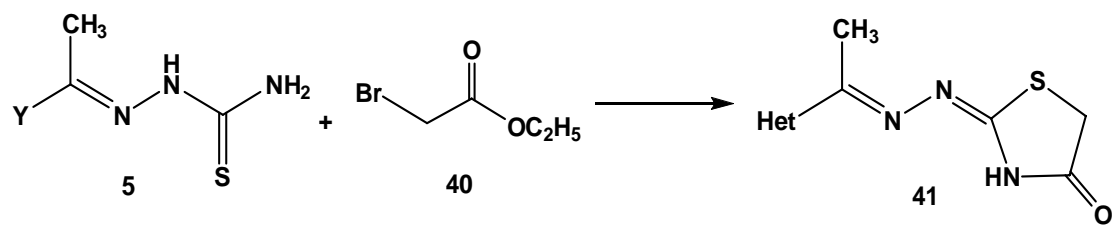

$\mathrm{Y}=$<smiles>Cc1ccccc1</smiles><smiles>Cc1ccc2c(c1)CCCC2</smiles>

\&<smiles>Cc1ccco1</smiles><smiles>Cc1cccs1</smiles><smiles>Cc1sc2nc3ccccc3nc2c1-n1cccc1</smiles>

\&<smiles>Cc1ccccn1</smiles>

$\&$<smiles>Cc1ccncc1</smiles>

\&<smiles>Cc1cc2ccccc2oc1=O</smiles>

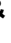<smiles>Cc1cc2c(ccc3ccccc32)o1</smiles>

Scheme 18. Synthesis of 2-hydrazono-4-thiazolidenones 
Cyclocondensation of ethyli denehydrazine1-carbothioamide5 with ethyl bromoethanoate(40) in an equal molar ratio, in ethanolic solution containing catalytic amount of fused sodium acetate, afforded thiazole-5(4H)-one derivative 41 .
However, reaction of two moles of ethyl bromoethanoate with one mole of compound 5 gave $\mathrm{N}$-ethoxycarbonylthiazole-5(4H)-one derivative $6,53,7842$, which was obtained from treatment of 40 with 41 (Scheme 19).

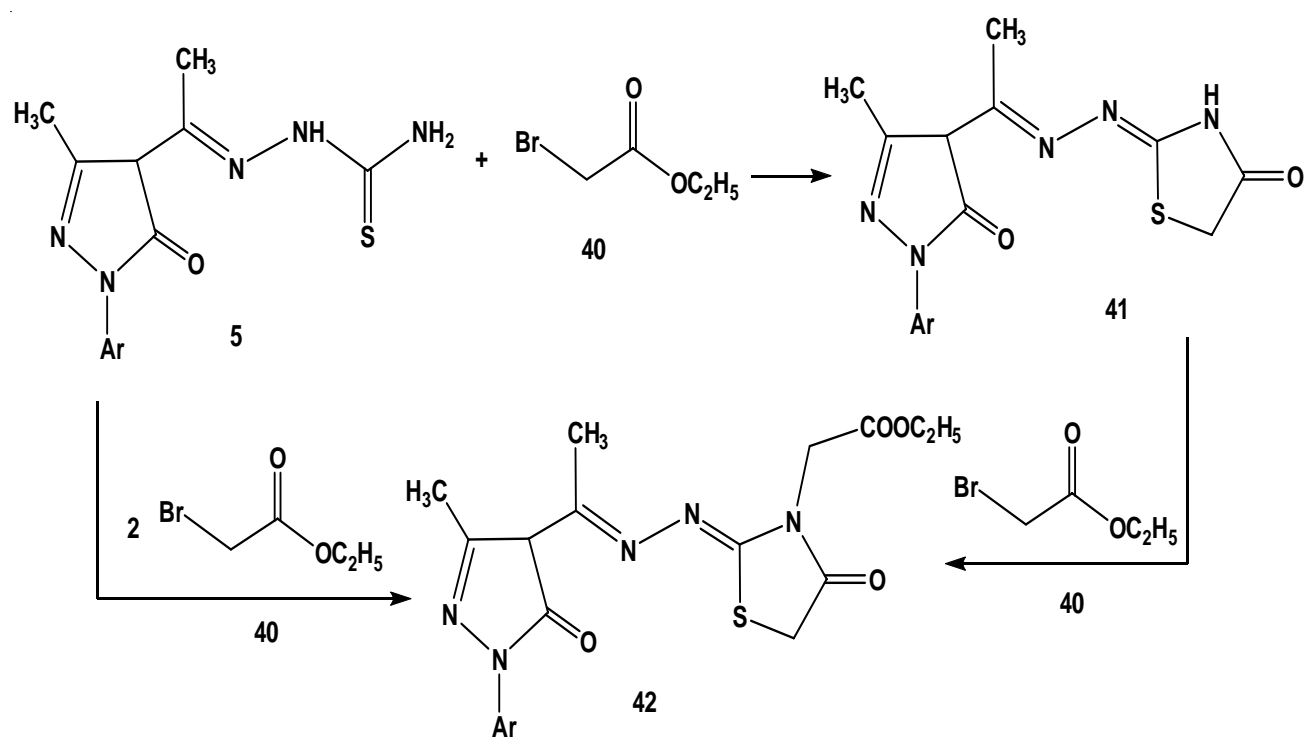

Scheme 19. Reaction of ethylidenehydrazine-1-carbothioamide with ethyl bromoethanoate

Treatment of arylethylidenethiosemicarbazide 3 with ethyl 2-bromopropanoate (43) under reflux condition in absolute ethanol/piperidine mixturefurnished 5-methyl-4-thiazolidenone ${ }^{43} 44$ (Scheme 20).<smiles>[Y]CCCOC(=O)C(C)Br</smiles><smiles>C/C(=N\N=C1/NC(=O)C(C)S1)c1ccc2c(c1)CCCC2</smiles>

Scheme 20. Reaction of arylethylidenethiosemicarbazide with ethyl 2-bromopropanoate

\section{Reaction with chloroacetonitrile}

Reaction of chloroacetonitrile with 1-[1-(2-naphthyl)ethylidene]thiosemicarbazide(3) in ethanol/triethylamine mixture, under reflux condition, underwent cyclization to give the respective 2,5-dihydro-4-aminothiazole derivative 4245 (Scheme 21). 


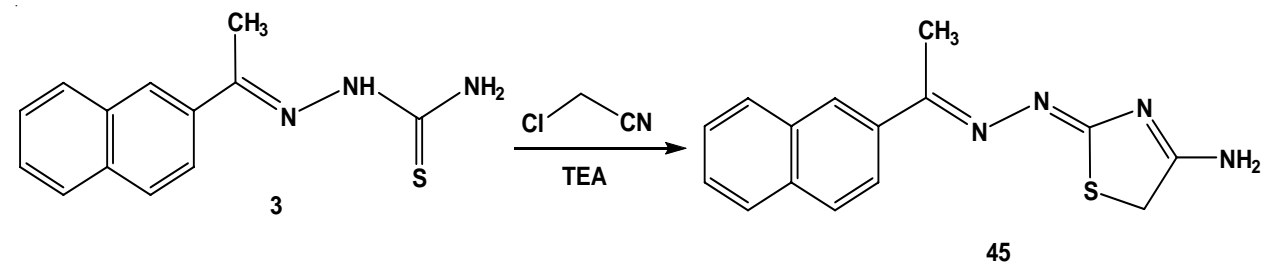

Scheme 21. Reaction of thiosemicarbazone with chloroacetonitrile

\section{Reaction with $\alpha$-halo dicarbonyl compounds}

Refluxing of ethylidenehydrazine-1carbothioamides 3 or 5 with a-halo dicarbonyl compounds such as; chloroacetylacetone
(46), ethyl chloroacetoacetate (47), and chloroacetoacetanilide (48) gave the respective 2-hydrazono-4-methylthiazoles ${ }^{20,42,43,52,57} 49$ a-c(Scheme 22).

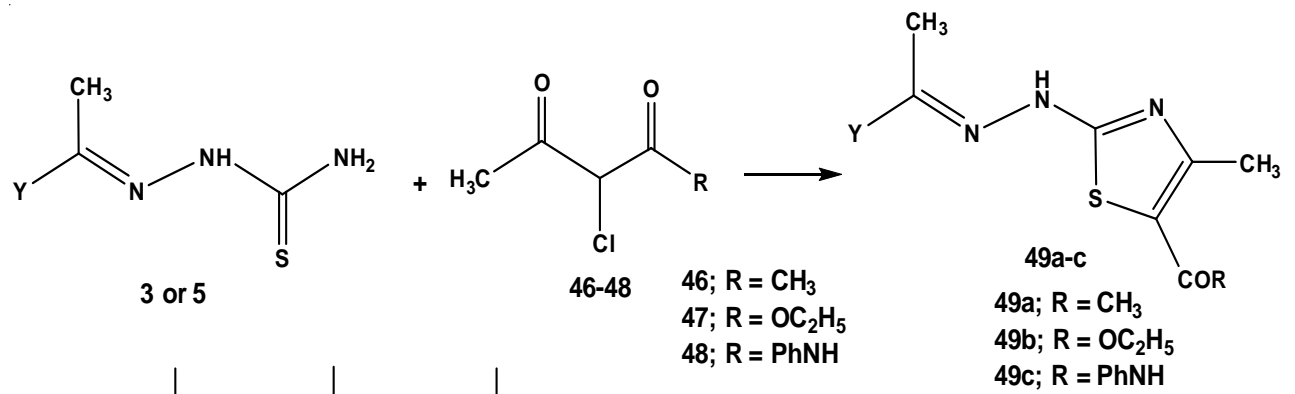<smiles>Cc1ccc(Cl)cc1</smiles>

$\&$<smiles>Cc1ccc(F)cc1</smiles><smiles>Cc1ccc2c(c1)CCCC2</smiles>
\&<smiles>Cc1cccs1</smiles>
\&<smiles>Cc1[nH]c(-c2ccccc2)c(-c2ccccc2)c1C</smiles><smiles>Cc1nc(S)n(-c2ccccc2)c1C</smiles>

$\&$<smiles>Cc1ccc2ccccc2c1</smiles>

\&<smiles>Cc1ccncc1</smiles>

$\&$<smiles>Cc1cccnc1</smiles>

\section{Scheme 22. Reaction of ethylidenehydrazine-1-carbothioamides with a-halo} dicarbonyl compounds

Conventional thermal heating or 3 or 5 and ethyl bromopyruvate (50) microwave irradiation of a mixture gave 4-ethoxycarbonylthiazole derivatives ${ }^{9851}$ of ethylidenehydrazine-1-carbothioamides (Scheme 23).

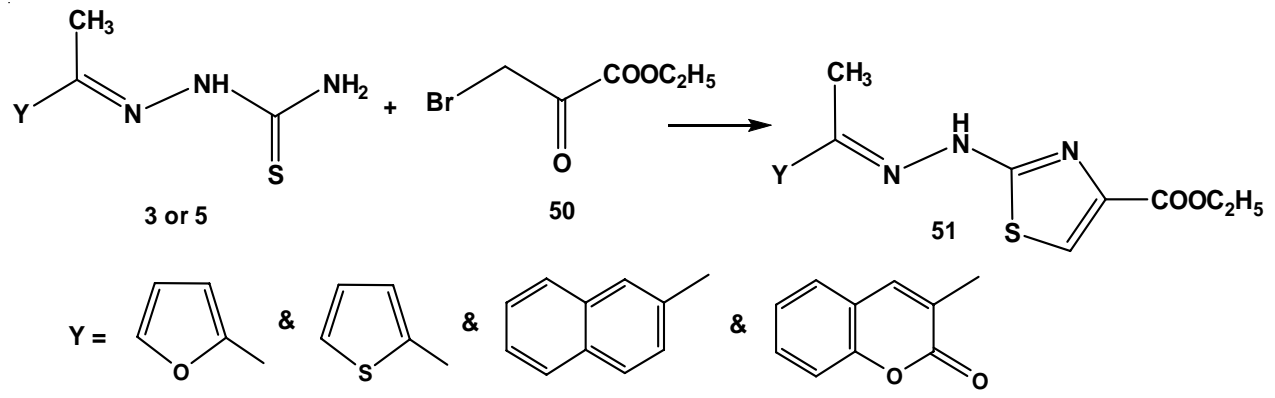

Scheme 23. Reaction of ethylidenehydrazine-1-carbothioamides with ethyl bromopyruvate 


\section{Reaction with dihalo compounds}

Treatment of ethylidenehydrazine-1. carbothioamide 5with 2,3-dichloroquinoxaline(52) in absolute ethanol, under reflux condition gave ethylidenehydrazonothiazolo[5,4- $b$ ]quinoxaline ${ }^{7} 53$ (Scheme 24).<smiles>C/C(=N/NC(N)=S)c1nc(-c2ccccc2)[nH]c1C</smiles><smiles>Clc1nc2ccccc2nc1Cl</smiles><smiles>C/C(=N\Nc1nc2nc3ccccc3nc2s1)c1nc(-c2ccccc2)n([TlH])c1C</smiles>

Scheme 24. Reaction of ethylidenehydrazine-1-carbothioamide with 2,3-dichloroquinoxaline

\section{Reaction with aldehydes}

Condensation of 1-[1-(9-arylidene-3methyl-5-phenyl-6,7,8,9-tetrahydro-[1,2,4] triazolo[3,4-b] quinazolin-1(5H)-yl) ethylidene] thiosemicarbazide (5) with 2-chlorobezaldehyde (54) gave the respective Schiff's base compound ${ }^{99} 55$ (Scheme 25).<smiles>C/C(=N/NC(N)=S)N1N=CN2C1=NC1=C(CCC/C1=C/[18F])C2c1ccccc1</smiles><smiles>CCI(C)C</smiles>

54<smiles>C/C(=N/NC(=S)/N=C/c1ccccc1Cl)N1N=CN2C1=NC1=C(CCC/C1=C/[Ga])C2c1ccccc1</smiles>

Scheme 25. Preparation of Schiff's base

\section{Reaction with $a, b$-unsaturatednitrile compounds}

The response of ethylidenehydrazine-1carbothioamide5 towards different acrylonitrile derivatives was investigated ${ }^{52,57}$. Thus, reaction of5with arylidenemalononitriles 56,2-cyano- $N, 3$ - diphenylacrylamide (57), and 3-aryl-2-cyano-prop2-enethioamide (58), in dioxane under microwave irradiation $^{52}$ or methanol under thermal conditions ${ }^{57}$ furnished the respective 1,3-thiazine derivatives ${ }^{52,57}$ 60a-c (Scheme 26). 
<smiles>CCC(C)=NNC(N)=S</smiles><smiles>Cc1[nH]c(-c2ccccc2)c(-c2ccccc2)c1C</smiles><smiles></smiles>

$56 ; Z=C N$ $57 ; \mathrm{Z}=\mathrm{CONHPh}$ $58 ; \mathrm{Z}=\mathrm{CSNH} 2$

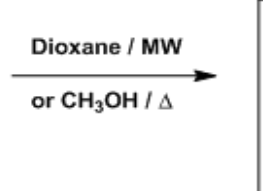<smiles>[Z]C(C)C([Al])S/C(N)=N\N=C(C)C</smiles>

$59 a-c$<smiles>[Z]C1=C(N)N=C(N/N=C(\[CH])C)SC1[Al]C</smiles>

Scheme 26. Reaction of ethylidenehydrazine-1-carbothioamide with acrylonitrile derivatives

Similarly, reaction of ethylidenehydrazine1-carbothioamide5 with ethoxymethylenemalononitrile (61)in refluxing methanol afforded 4-amino-2-

hydrazono-1,3-thiazine-5-carbonitrile ${ }^{57} 63$ via non-isolable intermediate 62 (Scheme 27).<smiles>C/C(=N\NC(N)=S)c1c(C)nc(S)n1-c1ccccc1</smiles>

5<smiles>Cc1nc(S)n(-c2ccccc2)c1/C=N\N</smiles>

63<smiles>CCOC=C(C#N)CO</smiles><smiles>CCOC(S/C(N)=N\N=C(/C)c1c(C)nc(S)n1-c1ccccc1)C(C#N)CO</smiles>

Scheme 27. Reaction of ethylidenehydrazine-1-carbothioamidewith ethoxymethylenemalononitrile

Treatment of an equimolar amounts of pyridine solution gave 2-hydrazono-4-aryl-2,3 2-[1-(2-pyridyl)ethylidene]hydrazine-1-carbothioamide(5) dihydrothiazole-5-carbonitriles ${ }^{10064}$ (Scheme 28). with arylmethylenemalononitriles 56 in<smiles>C/C(=N/N=C(/C)c1cccc(/C(C)=N/NC(N)=S)n1)c1ccccn1</smiles>

Scheme 28. Synthesis of 2,3-dihydrothiazole-5-carbonitriles 
On the other hand, reactions of pyrimidinethione derivative(67) or imino1-[1-(2-naphthyl)ethylidene]thiosemicarbazide(3) pyrimidinethione derivative ${ }^{42}(68)$, respectively with benzylidenemalononitrile 56 or (Scheme 29). ethoxymethylenemalononitrile(61) affordedamino-

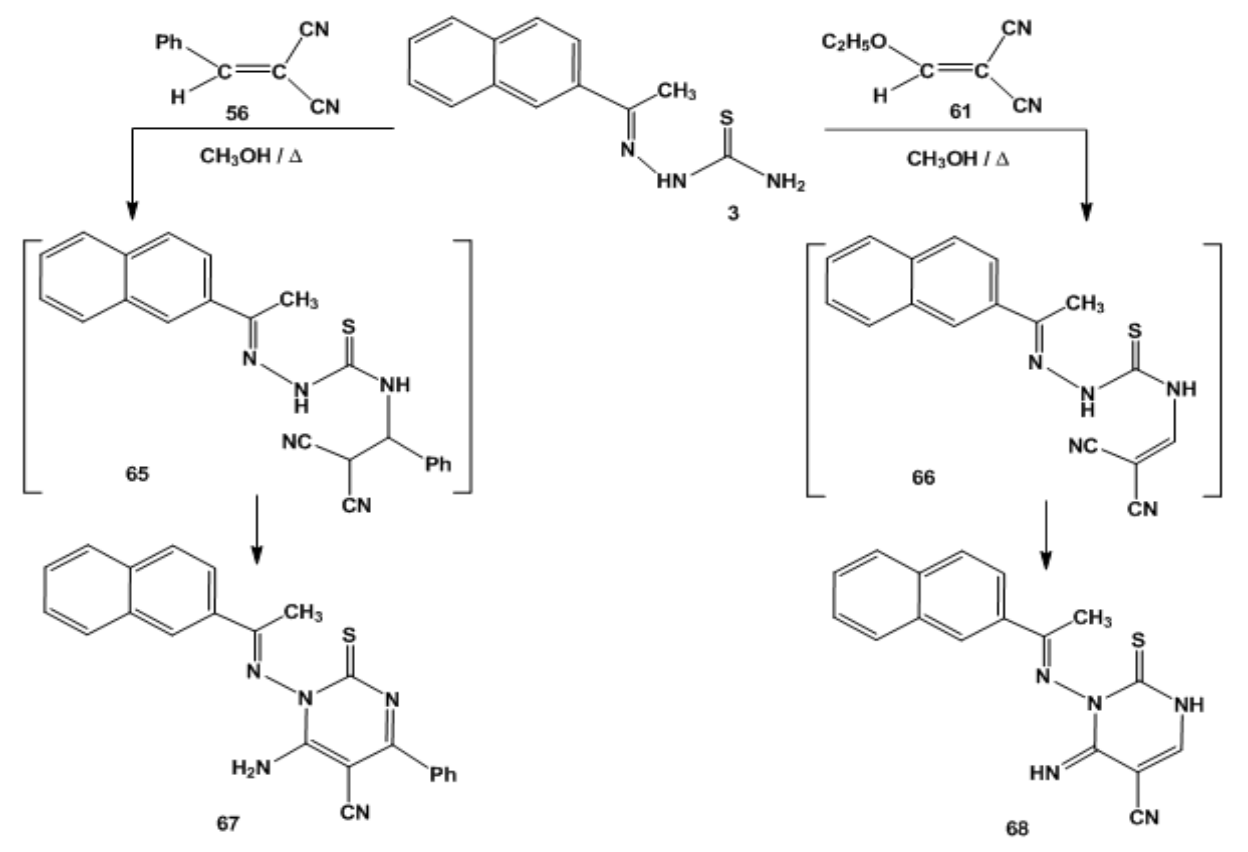

Scheme 29. Synthesis of pyrimidinethione derivatives

A mixture of 2-arylhydrazono-4-amino- 73 was obtained ${ }^{101}$ from the reactions of 1,3-thiazine-5,6,6-tricarbonitriles 72 and 6-amino- thiosemicarbazones 3 or 5 with tetracyanoethylene 2-thioxo-2,3-dihydropyrimidine-4,5-dicarbonitriles (69) (Scheme 30).

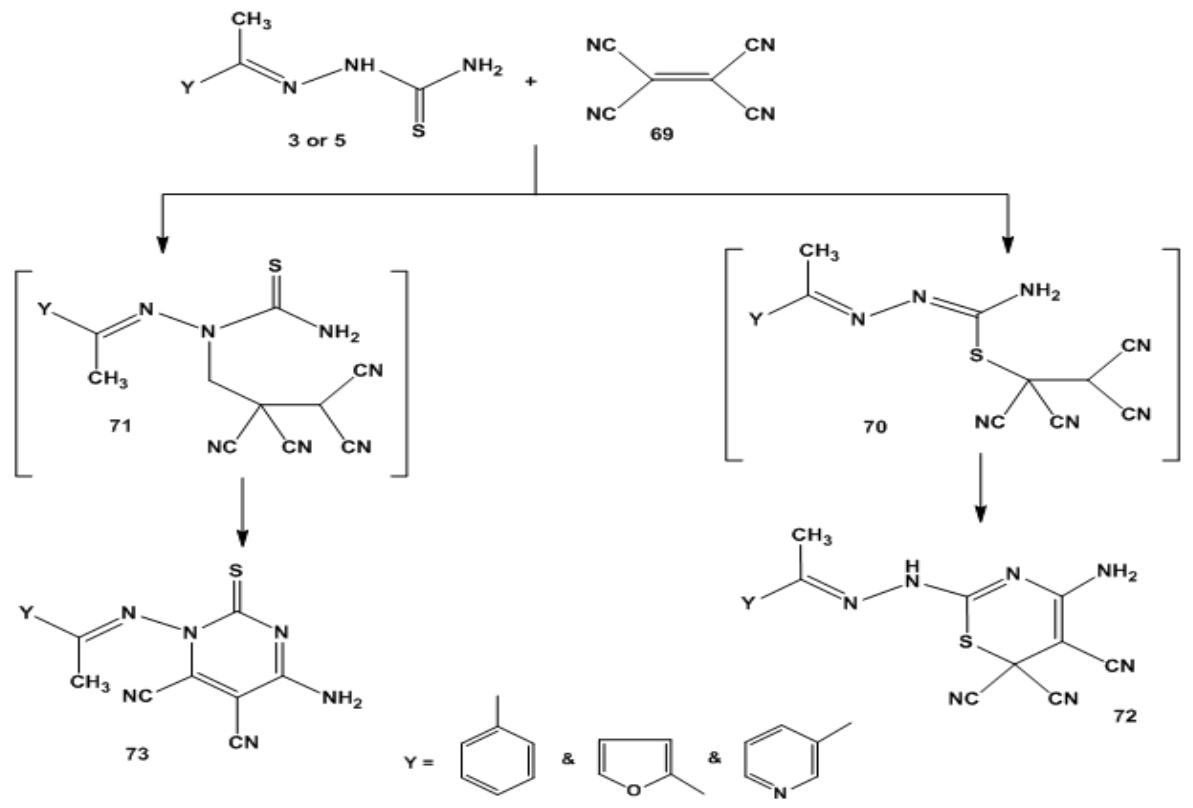

Scheme 30. Reaction of thiosemicarbazone with tetracyanoethylene 


\section{Reaction with anhydrides}

Cyclocondensation of ethylidenethiosemicar-bazides 3 or 5 with acetic anhydride (74) led to formation of $3,5-\mathrm{di}(\mathrm{N}$-acetylamino $)-[1,3,4]$ thiadiazole derivatives ${ }^{59,102,103} 77$. The isolable products were formed via acetylation of primary nitrogen of thiourea residue (intermediate 75), intramolecular cyclization of thiol group into imino group (intermediate 76), and acetylation of $\mathrm{NH}$ group of $[1,3,4]$ thiadiazole ring (Scheme 31$)$.<smiles>[Y]C(C)=NNC(=S)N[13CH2]C(C)=O</smiles>

3 or 5

74<smiles>[3H]CC</smiles><smiles>[Y]C1(C)SC(NOC(C)=O)=NN1C(C)=O</smiles><smiles>CC(=O)c1ccc(C)cc1</smiles><smiles>Cc1cc2ccc(Br)cc2oc1=O</smiles><smiles>Cc1cc2ccc(O)cc2oc1=O</smiles>

$\&$<smiles>Cc1cc2cc(Br)c(Br)cc2oc1=O</smiles>

Scheme 31. Reaction of thiosemicarbazone with acetic anhydride

Treatment of ethylidenehydrazine-1carbothioamides 3 or 5 with maleic anhydride (78) gave 2-[2-hydrazono-4-oxo-4,5-dihydrothiazol-5-yl] ethanoic acid derivatives ${ }^{8,4379}$ through thia-Michael reaction(Scheme 32).<smiles>[Y]C(C)=NNC(N)=S</smiles>

Scheme 32. Reaction of ethylidenehydrazine-1-carbothioamides with maleic anhydride

Treatment of thiosemicarbazone (5), containing indole moiety, with maleic anhydride (78) or phthalic anhydride (80) in boiling ethanol gave 2-[2-hydrazono-4-oxo-4,5-dihydrothiazol-5-yl] ethanoic acid derivative (81) or $N$ - substituted phthalimide derivative (82), respectively ${ }^{84}$ (Scheme 33). 


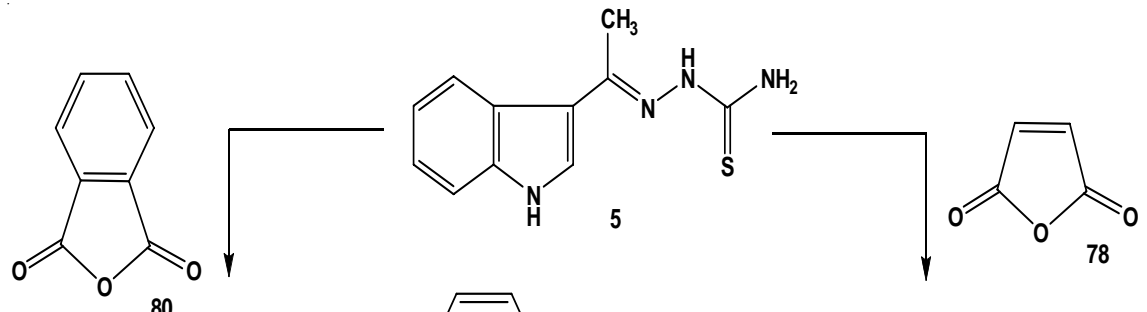<smiles>C/C=C\C1=C(C)C(=O)N(C(=S)N/N=C(\C)c2c[nH]c3ccccc23)C1=O</smiles><smiles>C/C(=N\N=C1/NC(=O)C(CC(=O)O)S1)c1c[nH]c2ccccc12</smiles>

Scheme 33. Reactions of thiosemicarbazone with maleic anhydride and phthalic anhydride

\section{Reaction with hydrochloric and sulfuric acids}

Refluxing of thiosemicarbazone (5), containing benzofuran moiety, with methanol/

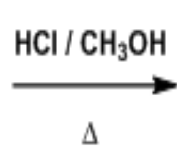

$\Delta$ hydrochloric acid mixture furnished $[1,2,4]$ triazoline3-thione derivative ${ }^{68} 83$ (Scheme 34).<smiles>[R2]c1cc2occc2c(OC)c1/C(C)=N/NC(N)=S</smiles>

5<smiles>[R20]c1cc2occc2c(OC)c1C1(C)NNC(=S)N1</smiles>

83

Scheme 34. Reaction of thiosemicarbazone with hydrochloric acid

$[1,2,4]$ Triazepino[6,5-c]quinolin-6(7H)one (84) was prepared through dehydration of ethylidenehydrazine-1-carbothioamide (5), containing hydroxyquinolone moiety, by sulfuric acid at room temperature ${ }^{74}$ (Scheme 35 ).<smiles>C/C(=N\NC(N)=S)c1c(O)c2ccccc2[nH]c1=O</smiles>

Scheme 35. Dehydration of ethylidenehydrazine-1-carbothioamide

\section{Reaction with dialkyl but-2-ynedioate}

Refluxing of ethylidenehydrazine1-carbothioamides 3 or 5 with dimethyl but-2-ynedioate or diethyl but-2-ynedioate in methanol afforded the respective alkyl 2-[2-hydrazono-4-oxothiazol-5(4H)-ylidene] ethanoate derivatives 42,52,57,84,100,104,10588a,b (Scheme 36). 


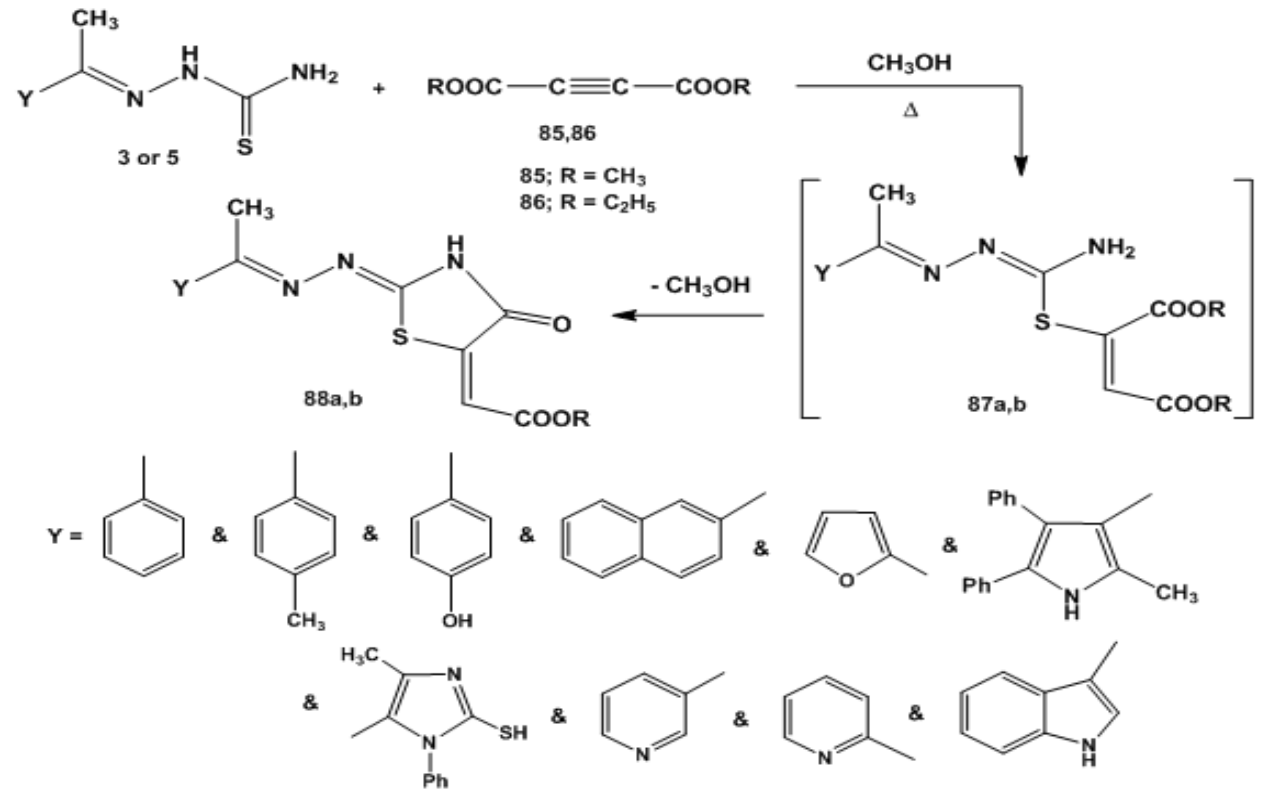

Scheme 36. Reaction of ethylidenehydrazine-1-carbothioamides with dialkyl but-2-ynedioate

\section{Self-condensation Reaction}

Microwave irradiation of ethylidenehydrazine-

1-carbothioamides3 or 5led to self-condensation<smiles>[Y]C(C)=NNC(N)=S</smiles>
and give3,4-diazahex-2,4-diene derivatives $89^{15}$ (Scheme 37)<smiles>[Y]C(C)=NN=C([Y])C</smiles>

89

Scheme 37. Microwave irradiation of ethylidenehydrazine-1-carbothioamides

Vilsmeier-Haack Reaction

Treatment of bis-thiosemicarbazones 90

respective 6,8-bis-pyrazolylcoumarine derivative ${ }^{106}$ 92 (Scheme 38).

with Vilsmeier-Haack reagent furnished the<smiles>C/C(=N/NS(C)(=O)=O)c1cc2c(C)cc(=O)oc2c(/C(C)=N\NS(=O)(=O)[O-])c1O</smiles><smiles>C/C(=N/N(C=O)C=O)c1cc2c(C)cc(=O)oc2c(/C(C)=N/N(C#N)C=O)c1O</smiles><smiles>Cc1cc(=O)oc2c(-c3nn(S(C)(=O)=O)cc3C=O)c(O)c(-c3nn(C(N)=O)cc3C=O)cc12</smiles>

Scheme 38. Reaction of bis-thiosemicarbazone with Vilsmeier-Haack reagent 
Biological activity

Antimicrobial activity

Ethylidenethiosemicarbazide 3 or 5 were proclaimed to display a wide range of antibacterial and antifungal activities with different pharmacophore moieties $4,6,7,25,39,58,64,65,67,68,72$ (Chart 1).<smiles>[Y]C(C)=NNC(N)=S</smiles>
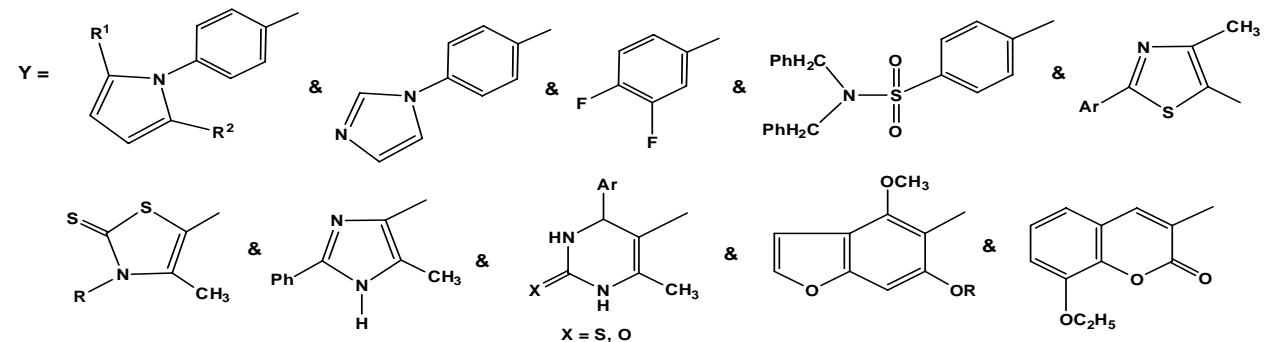

Chart 1. Ethylidenethiosemicarbazide having antimicrobial activity

\section{Antiviral activity}

Ethylidenethiosemicarbazide with aryl or benzimidazole substituents were evaluated as<smiles>[Y]C(C)=NNC(N)=S</smiles><smiles></smiles>

Chart 2. Ethylidenethiosemicarbazide havingantiviral activity

\section{Anticancer activity}

Different alicyclic, aryl, or heterocyclic moieties introduced to thiosemicarbazone scaffolds antiviral agents and showed moderate activity in most cases ${ }^{5,33,107,108}$ (Chart 2).

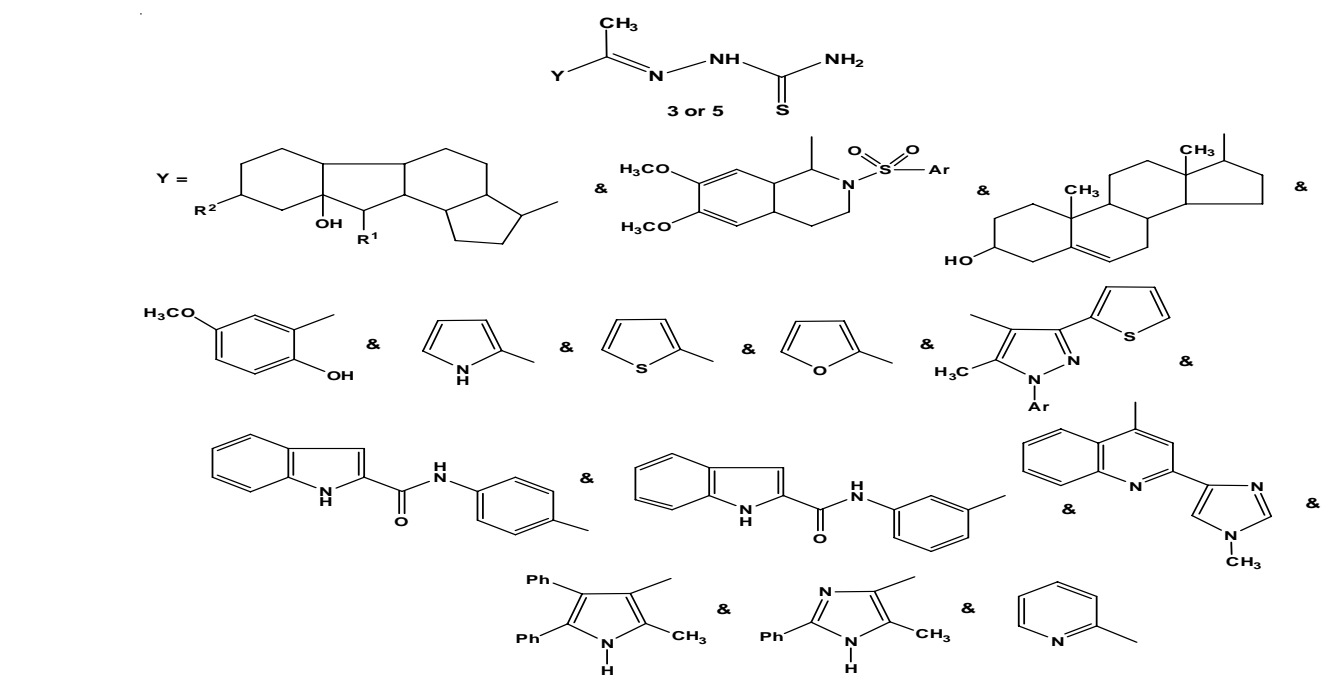

Chart 3. Ethylidenethiosemicarbazide having anticancer activity 


\section{Anticonvulsant activity}

Thiosemicarbazones are promising anticonvulsant candidates ${ }^{8}$ that contain non-polar groups(aryl or heteroaryl) and thiourea residue (polar group which is responsible for hydrogen bonding) (Chart 4).<smiles>[R]c1c(O)c(/C(C)=N/NC(N)=S)c(OC)c2ccoc12</smiles>

Chart 4. Ethylidenethiosemicarbazide having anticonvulsant activity

\section{Antiparasitic activity}

Recent research focuses on developing new drugs for Chagas diseases, caused by the protozoan parasite Trypanosoma Cruzi.
Ethylidenethiosemicarbazides were evaluated and displayed higher activity against $T$. Cruzi $i^{9,10,24,38}$ (Chart 5).<smiles>[R]c1ccc(/C(C)=N/NC(N)=S)cc1[R]</smiles>

Chart 5. Ethylidenethiosemicarbazide having antiparasitic activity

\section{Miscellaneous}

Other pharmaceutical applicationsof ethylidenethiosemicarbazides such as; Tyrosinase inhibitors $^{51}$, antihypertensive ${ }^{66}$, antioxidant ${ }^{36}$, antiamoebic ${ }^{3}$, and antitubercular agents ${ }^{2}$ have been reported (Chart 6).

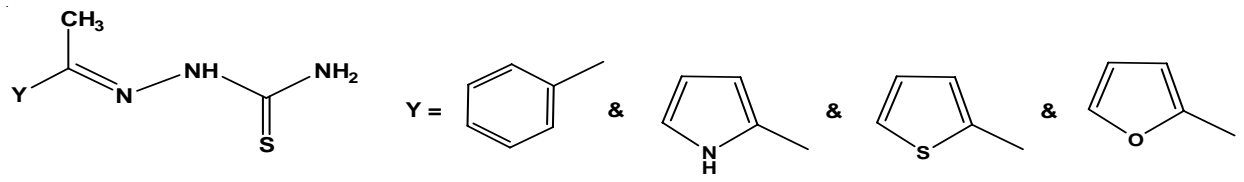

Tyrosinase inhibitors<smiles>CC1=C(/C(C)=N/NC(N)=S)C([Al])NC(=S)N1</smiles>

Antihypertensive agent<smiles>C/C(=N/NC(N)=S)c1c(O)ccc2ccc(=O)oc12</smiles>

Antiamoebic agent<smiles>C/C(=N\NC(N)=S)c1ccc(NC(=O)c2ccccc2C(=O)O)cc1</smiles><smiles>C/C(=N\NC(N)=S)c1sc(C2CCCCC2)nc1C</smiles>

Antitubercular agent

Chart 6. Miscellaneous activities of Ethylidenethiosemicarbazide 


\section{CONCLUSION}

Ethylidenethiosemicarbazides have been exploited as starting scaffolds for synthesis of different azoles, azines, and fused heterocyclic compounds. Also, ethylidenethiosemicarbazides were associated with a broad spectrum of biological activities.

\section{ACKNOWLEDGMENT}

The authors represent their glory to King Abdulaziz University for funding our research project (grant No: 1-17-01-006-0001).

\section{REFERENCES}

1. dos Santos, T. A. R.; da Silva, A. C.; Silva, E. B.; de Moraes Gomes, P. A. T.; Espíndola, J. W. P.; de Oliveira Cardoso, M. V.; Moreira, D. R. M.; Leite, A. C. L.; Pereira, V. R. A. Biomed. Pharmacother., 2016, 82, 555-560.

2. Abhale, Y. K.; Shinde, A.; Deshmukh, K. K.; Nawale, L.; Sarkar, D.;Mhaske, P. C.Med. Chem. Res., 2017, 26, 2557-2567.

3. Iqbal, P. F.; Bhat, A. R.; Azam, A. Eur. J. Med. Chem., 2009, 44, 2252-2259.

4. Reis, D. C.; Despaigne, A. A. R.; Da Silva, J. G.; Silva, N. F.; Vilela, C. F.; Mendes, I. C.; Takahashi, J. A.; Beraldo, H.Molecules., 2013, 18, 12645-12662.

5. Vitale, G.; Corona, P.; Loriga, M.; Carta, A.; Paglietti, G.; Giliberti, G.; Sanna, G.; Farci, P.; Marongiu, M. E.; La Colla, P. Eur. J. Med. Chem., 2012, 53, 83-97.

6. Bashandy, M. S. Asian J. Chem. 2011, 23, 3191-3201.

7. Abdel-Wahab, B. F.; Awad, G. E. A.; Badria, F. A. Eur. J. Med. Chem., 2011, 46, 1505-1511.

8. Ragab, F. A.; El-Sayed, N. A. M..; Eissa, A. A. M.; El Kerdawy, A. M. Chem. Pharm. Bull., 2010, 58, 1148-1156.

9. Costa, L. B.; de Oliveira Cardoso, M. V.; de Oliveira Filho, G. B.; de Moraes Gomes, P. A. T.; Espíndola, J. W. P.; de Jesus Silva, T. G.; Torres, P. H. M.; Junior, F. P. S.; Martin, J.; Queiroz de Figueiredo, R. C. B.; Leite, A. C. L. Bioorg. Med. Chem., 2016, 24, 1608-1618.

10. de Oliveira Filho, G. B.; de Oliveira Cardoso, M. V.; Espíndola, J.W.P.; Oliveira e Silva, D. A.; Ferreira, R. S.; Coelho, P. L.; dos Anjos, P. S.; de Souza Santos, E.; Meira, C.S.; Moreira, D. R.M.; Soares, M. B. P.; Leite, A. C. L. Eur. J. Med. Chem., 2017, 141, 346-361.

11. Narkhede, H.I.; Nevagi, R.J.;Kumbhare, M.; Kaur, P. Der Pharm. Chem., 2014, 6, 221-227.

12. Netalkar, P. P.; Netalkar, S. P.; Revankar, V. K.
Appl. Organomet. Chem., 2015, 29, 280-289.

13. Abdelrazek, F. M.; Gomha, S. M.; Metz, P.; Abdalla, M. M. J. Heterocycl. Chem., 2017, 54, 618-623.

14. Gomha, S. M.; Ahmed, S. A.; Abdelhamid, A. O. Molecules., 2015, 20, 1357-1376.

15. Chattopadhyay, G.; Ray, P. S. Synth. Commun., 2011, 41, 2607-2614.

16. Moreira, D. R. M.; Santos, D. S.; do Espirito Santo, R. F.; dos Santos, F. E.; de Oliveira Filho, G. B.; Leite, A. C. L.; Soares, M. B. P.; Villarreal, C. F. Chem. Biol. Drug Des., 2017, 90, 297-307.

17. Thanusu, J.; Kanagarajan, V.; Gopalakrishnan, M. Bioorg. Med. Chem. Lett., 2010, 20, 713-717.

18. Gomha, S. M.; Riyadh, S. M.; Mahmmoud, E. A.; Elaasser, M. M. Chem. Heterocycl. Compd., 2015, 51, 1030-1038.

19. Riyadh, S. M.; Deawaly, A. A.; Ahmed, H. E. A.; Afifi, T. H.; Ihmaid, S. Med. Chem. Res., 2017, 26, 1956-1968.

20. Makam, P.; Thakur, P. K.; Kannan, T. Eur. J. Pharm. Sci., 2014, 52, 138-145.

21. Chimenti, F.; Bizzarri, B.; Bolasco, A.; Secci, D.; Chimenti, P.; Granese, A.; Carradori, S.; D'Ascenzio, M.; Scaltrito, M. M.; Sisto, F. J. Heterocycl. Chem., 2010, 47, 1269-1274.

22. Makam, P.; Kankanala, K.; Prakash, A.; Kannan, T. Eur. J. Med. Chem., 2013, 69, 564-576.

23. Arshad, A.; Osman, H.; Bagley, M. C.; Lam, C. K.; Mohamad, S.; Zahariluddin, A. S. M. Eur. J. Med. Chem., 2011, 46, 3788-3794.

24. Blau, L.; Menegon, R. F.; Trossini, G. H. G.; Dutra Molino, J. V.; Vital, D. G.; Barretto Cicarelli, R. M.; Duó Passerini, G.; Bosquesi, P. L.; Chin, C. M. Eur. J. Med. Chem., 2013, 67, 142-151.

25. Jagadeesh, M.; Kumar, V. A.; Ramachandraiah, C.; Reddy, A. V. J. Appl. Pharm. Sci., 2013, 3, 
111-115.

26. Ayyash, A. N.; Jaffer, H. J.;Tomma, J. H. Am. J. Org. Chem., 2014, 4, 52-62.

27. Saravanan, R. R.; Seshadri, S.; Gunasekaran, S.; R. Mendoza-Meroño, R.; Garcia-Granda, S. Spectrochim. Acta, Part A Mol. Biomol. Spect., 2015, 139, 321-328.

28. Ma, J.-X.; Lei, X.-F.; Wang, Y.-H.; Sun, Y.-Y. Z. Kristallograph. - New Crystal Str., 2013, 228, 453-454.

29. Anbazhagan, R.; Sankaran, K. R. Spectrochim. Acta, Part A Mol. Biomol. Spect., 2015, 135, 984-993.

30. Pirbasti, F. G.; Mahmoodi, N. O.; Shiran, J. A. J. Sulfur Chem., 2016, 37, 196-210.

31. Akgemci, E. G.; Saf, A. O.; Tasdemir, H. U.; Turkkan, E.; Bingol, H.; Turan, S. O.; Akkiprik, M. Spectrochim. Acta, Part A Mol. Biomol. Spect., 2015, 136, 719-725.

32. Kilic-Cikla, I.; Guveli, S.; Bal-Demirci, T.; Aygun, M.; Ulkuseven, B.; Yavuz, M. Polyhedron., 2017, 130, 1-12.

33. El-Sabbagh, O. I. Arch. Pharm., 2013, 346, 733-742.

34. Salem, M. A.; Thabet, H. K. H.; Helal, M. H.; Abdelaal, A. S.; Ammar, Y. A. Chem. Sci. J., 2011, 32, 1-12.

35. Erol, I.; Sahin, Z.; Ozcan, L. Polymer Eng. Sci., 2013, 53, 1383-1393.

36. Bayoumi, W. A.; Elsayed, M. A.; Baraka, H. N.; Abou-Zeid, L. Arch. Pharm., 2012, 345, 902910.

37. Salem, M. A. Org. Chem. Indian J., 2009, 5, 386-396.

38. Fathalla, O.A.;Haiba, M.E.;Anwar, M.M.;Almutairi, M. S.; Maghraby, A.S.; Bahgat, M. M. Res. Chem. Intermed., 2013, 39, 2157-2185.

39. More, U. A.; Joshi, S. D.; Aminabhavi, T. M.; Gadad, A. K.; Nadagouda, M. N.; Kulkarni, V. H. Eur. J. Med. Chem., 2014, 71, 199-218.

40. Desai, N. C.; Joshi, V. V.; Rajpara, K. M.; Vaghani, H. V.; Satodiya, H. M. Med. Chem. Res., 2013, 22, 1893-1908.

41. El-Sabbagh, O. I.; Ibrahim, S. M.; Baraka, M. M.; Kothayer, H. Arch. Pharm., 2010, 343, 274-281.

42. Gomha, S. M.; Badrey, M. G. J. Chem. Res., 2013, 86-90.

43. Haiba, M. E.; Abd El-Karim, S. S.; Gouhar, R. S.; El-Zahar, M. I.; El-Awdan, S. A. Med. Chem. Res., 2014, 23, 3418-3436.
44. Sharma, S.; Bedi, M.; Varshney, S.; Varshney, A. K. Indian J. Chem. Soc., 2012, 89, 41-50.

45. Khalifa, N. M.; Mohamed, M. S.; Zaki, M. E.; Al-Omar, M. A.; Yasser M. Zohny, Y. M. Res. Chem. Intermed., 2014, 40, 1565-1574.

46. Gan, C.; Fan, L.; Huang, Y.; Liu, Z.; Cui, J. Med. Chem., 2013, 9, 846-854.

47. Gan, C.-F.; Liu, Z.-P.;Wei, W.-X.; Huang, Y.-M.; Cui, J.-G. Huaxue Yanjiu Yu Yingyong(Chem. Res. Appl.)., 2013, 25, 647-654.

48. Liao, L.; Jiao, Y.-X.; Yao, Q.-C.; Huang, Y.-M. Huaxue Shiji., 2012, 34, 211-215.

49. Hassan, A. A.; Ibrahim, Y. R.; El-Sheref, E. M.; Abdel-Aziz, M.; Brase, S.; Nieger, M. Arch. Pharm., 2013, 346, 562-570.

50. Tyagi, M.; Chandra, S.; Tyagi, P. Spectrochim. Acta, Part A Mol. Biomol. Spect., 2014, 117, 1-8.

51. Dong, H.; Liu, J.; Liu, X.; Yu, Y.; Cao, S. Bioorg. Chem., 2017, 75, 106-117.

52. Gomha, S. M.; Riyadh, S. M.; Mahmmoud, E. A.; Elaasser, M. M. Heterocycles., 2015, 91, 1227-1243.

53. Abdelall, M. M. Phosphorus, Sulfur Silicon., 2009, 184, 2208-2226.

54. Rana, A.; Parekh, N.; Dabhi, H.; Bhoi, D.; Kumari, N. E-J. Chem., 2011, 8, 1820-1831.

55. Rana, A. K.; Parekh, N. R.; Dabhi, H. R.; Nadkarni, S. S. E-J. Chem., 2009, 6, 747-752.

56. Chapkanov, A. Bulg. Chem. Ind., 2008, 79, 13-16.

57. Gomha, S. M.; Riyadh, S. M.; Abbas, I. M.; Bauomi, M. A. Heterocycles., 2013, 87, 341-356.

58. Eliazyan, K. A.; Knyazyan, A. M.; Pivazyan, V. A.; Ghazaryan, E. A.; Harutyunyan, S. V.; Yengoyan, A. P. J. Heterocycl. Chem., 2013, 50, 1083-1088.

59. Wang, H.-C.; Li, R.-O.; Dong, H.-R.; Dong, H.-S. Indian J. Chem., 2010, 49B, 521-525.

60. Wang, H.-C.; Li, R.-O.; Dong, H.-R.; Dong, H.-S. Indian J. Heterocycl. Chem., 2009, 19, 99-100.

61. Ingale, A. P. J. Chem. Pharm. Res., 2014, 6, 460-464.

62. Ismail, T.; Rossouw, D. D.; Beukes, P.; Slabbert, J. P.; Smith, G. S. Inorg. Chem. Commun., 2013, 33, 154-157.

63. Cobeljic, B.; Pevec, A.; Turel, I.; Spasojevic, V.; Milcic, M.; Mitic, D.; Sladic, D.; Andelkovic, K. Polyhedron., 2014, 69, 77-83.

64. Lanjewar, K. R.; Ghatole, A. M.; Bhongade, 
R. P.; Gaidhane, M. K.; Rewatkar, S. B. World J. Pharm. Res., 2014, 3, 1445-1453.

65. Nevagi, R. J.; Narkhede, H. I. DerPharma Chim., 2014, 6, 135-139.

66. Narkhede, H. I.; Nevagi, R. J.; Kumbhare, M.; Kaur, P. Der Pharm. Chem., 2014, 6, 221-227.

67. Lanjewar, K. R.; Ghatole, A. M.; Gaidhane, M. K. Int. J. Pharm. Pharmecuit. Sci., 2013, 5, 601-603.

68. Abdou, S. E.; El-Qusy, S. M.; Ghabrial, S. S.; Haggag, M. I. Modern Appl. Chem., 2011, 5, 140-149.

69. Abdel-Gawad, H.; Mohamed, H. A.; Dawood, K. M.; Badria, F. A. Chem. Pharm. Bull., 2010, 58, 1529-1531.

70. Gomha, S. M.; Khalil, K. D. Molecules., 2012, 17, 9335-9347.

71. Thota, S.; Nadipelly, K.; Shenkesi, A.; Yerra, R. Med. Chem. Res., 2015, 24, 1162-1169.

72. Mohamed, H. M.; Abd El-Wahab, A. H. F.; Ahmed, K. A.; El-Agrody, A. M.; Bedair, A. H.; Eid, F. A.; Khafagy, M. M. Molecules., 2012, 17, 971-988.

73. Cushing, T. D.; Baichwal, V.; Berry, K.; Billedeau, R.; Bordunov, V.; Broka, C.; Cardozo, M.; Cheng, P.; Clark, D.; Dalrymple, S.; DeGraffenreid, M.; Gill, A.; Hao, X.; Hawley, R. C.; He, X.; Jaen, J. C.; Labadie, S. S.; Labelle, M.; Lehel, C.; Lu, P.-P.; McIntosh, J.; Miao, S.; Parast, C.; Shin, Y.; Sjogren, E. B.; Smith, M.-L.; Talamas, F. X.; Tonn, G.; Walker, K. M.; Walker, N. P. C.; Wesche, H.; Whitehead, C.; Wright, M.; Browner, M. F. Bioorg. Med. Chem. Lett., 2011, 21, 417-422.

74. Sankaran, M.; Kumarasamy, C.; Chokkalingam, U.; Mohan, P. S. Bioorg. Med. Chem. Lett., 2010, 20, 7147-7151.

75. Pingaew, R.; Prachayasittikul, S.; Ruchirawat, S.; Prachayasittikul, V. Med. Chem. Res., 2013, 22, 267-277.

76. Geies, A. A.; Elossaily, Y. A.; Moustafa, O. S. Russ. J. Bioorg. Chem., 2012, 38, 526-532.

77. Gaber, A. M.; Geies, A. A. Afinidad LXVI., 2010, 546, 154-159.

78. Bedair, A. H.; Abd el-wahab, H. F.; El-agrody, A. M.; Ali, F. M.; Halawa, A. H.; El-Sherbiny, G. M. J. Serbian Chem. Soc., 2006, 71, 459-469.

79. Aly, A. S.; Abu-Zied, K. M.; Gaafar, A. M. Phosphorus, Sulfur Silicon Relat. Elem.,
2008, 183, 3063-3078.

80. Abdelhamid, A. O.; Ismail, Z. H.; Abdel-Aziem, A. J. Chem. Res., 2007, 609-616.

81. Farghaly, T. A.; Abdallah, M. A.; Masaret, G. S.; Muhammad, Z. A. Eur. J. Med. Chem., 2015, 97, 320-333.

82. Gomha, S. M.; Zaki, Y. H.; Abdelhamid, A. O. Molecules., 2015, 20, 21826-21839.

83. Abdelhamid, A. O; Gomha, S. M. Synth. Commun., 2017, 47, 1409-1414.

84. Abdelhamid, A. O; Gomha, S. M.; Kandeel, S. M. J. Heterocycl. Chem., 2017, 54, 1529-1536.

85. Gomha, S. M.; Edrees, M. M.; Faty, R. A. M.; Muhammad, Z. A.; Mabkhot, Y. Chem. Cent. J., 2017, 11:37.

86. Khidre, R. E.; El-Gogary, S. R.; Mostafa, M. S. J. Heterocycl. Chem., 2017, 54, 2511-2519.

87. Gomha, S. M.; Farghaly, T. A.; Sayed, A. R. J. Heterocycl. Chem., 2017, 54, 1537-1542.

88. Jadav, S. S.; Kaptein, S.; Timiri, A.; De Burghgraeve, T.; Badavath, V. N.; Ganesan, R.; Sinha, B. N.; Neyts, J.; Leyssen, P.; Jayaprakash, V. Bioorg. Med. Chem. Lett., 2015, 25, 1747-1752.

89. Secci, D.; Carradori, S.; Bizzarri, B.; Bolasco, A.; Ballario, P.; Patramani, Z.; Fragapane, P.; Vernarecci, S.; Canzonetta, C.; Filetici, P. Bioorg. Med. Chem., 2014, 22, 1680-1689.

90. Carradori, S.; Rotili, D.; De Monte, C.; Lenoci, A.; D’Ascenzio, M.; Rodriguez, V.; Filetici, P.; Miceli, M.; Nebbioso, A.; Altucci, L.; Secci, D.; Mai, A. Eur. J. Med. Chem., 2014, 80, 569-578.

91. Chimenti, F.; Bolasco, A.; Secci, D.; Chimenti, P.; Granese, A.; Carradori, S.; Yanez, M.; Orallo, F.; Ortuso, F.; Alcaro, S. Bioorg. Med. Chem., 2010, 18, 5715-5723.

92. Chimenti, F.; Secci, D.; Bolasco, A.; Chimenti, P.; Granese, A.; Carradori, S.; D’Ascenzio, M.; Yáñez, M.; Orallo, F. Chem. Med. Commun., 2010, 1, 61-72.

93. de Oliveira Cardoso, M. V.; Pessoa de Siqueira, L. R.; da Silva, E. B.; Costa, L. B.; Hernandes, M. Z.; Rabello, M. M.; Ferreira, R. S.; da Cruz, L. F.; Moreira, D. R. M.; Pereira, V. R. A.; Brelaz de Castro, M. C. A.; Bernhardt, P. V.; Leite, A. C. L. Eur. J. Med. Chem., 2014, 86, 48-59.

94. Salem, M. E.; Darweesh, A. F.; Mekky, A. E. M.; Farag, A. M.; Elwahy, A. H. M. J. Heterocycl. Chem., 2017, 54, 226-234. 
95. Yusufzai, S. K.;Osman, H.; Khan, M. S.; Mohamad, S.;Sulaiman, O.; Parumasivam, T.; Gansau, J. A.; Noviany, N. J. Med. Chem. Res., 2017, 26, 1139-1148.

96. Sweidan, K.; Sabbah, D. A.; Bardaweel, S.; AbuSheikha, G.; Al-Qirim, T.; Salih, H.; ElAbadelah, M. M.; Mubarak, M. S.; Voelter, W.Can. J. Chem., 2017, 95, 858-862.

97. D’Ascenzio, M.; Bizzarri, B.; De Monte, C.; Carradori, S.; Bolasco, A.; Secci, D.; Rivanera, D.; Faulhaber, N.; Bordon, C.; Jones-Brando, L. Eur. J. Med. Chem., 2014, 86, 17-30.

98. Carradori, S.; D’Ascenzio, M.; De Monte, C.; Secci, D.; Yanez, M. Arch. Pharm., 2013, 346, 17-22.

99. Dawoud, N. T. A. Chem. Sci. Trans., 2017, 6, 114-128.

100. Aly, A. A.; Ishak, E. A.; Brown, A. B. J. Sulfur Chem., 2014, 35, 382-393.

101. Hassan, A.; Ibrahim, Y.R.; El-Sheref, E. M.; Brase, S. J. Heterocycl. Chem., 2016, 53, 876-881.
102. Gireesh, T.; Khan, G. M. Z.; Kamble, R. R. J. Indian Chem. Soc., 2011, 88, 1459-1463.

103. De Monte, C.; Carradori, S.; Secci, D.; D’Ascenzio, M.; Guglielmi, P.; Mollica, A.; Morrone, S.; Scarpa, S.; Aglian, A. M.; Giantulli, S.; Silvestri, I. Eur. J. Med. Chem., 2015, 105, 245-262.

104. Darehkordi, A.; Saidi, K.; Mohammad Reza Islami, M. R. Arkivoc.,2007, (1), 180-188.

105. Hassan, A. A.; Ibrahim, Y. R.; Aly, A. A.; EISheref, E. M., Yamamoto, T. J. Heterocycl. Chem., 2013, 50, 473-477.

106. Nagamallu, R.; Srinivasan, B.; Ningappa, M. B.; Kariyappa, A. K. Bioorg. Med. Chem. Lett., 2016, 26, 690-694.

107. Asthana, S.; Shukla, S.; Ruggerone, P.; Vargiu, A. V. Biochemistry., 2014, 53, 6941-6953.

108. Asthana, S.; Shukla, S.; Vargiu, A. V.; Ceccarelli, M.; Ruggerone, P.; Paglietti, G.; Marongiu, M. E.; Blois, S.; Giliberti, G.; La Colla, P. Biochemistry., 2013, 52, 3752-3764. 